\title{
Women Entrepreneurship of Sylhet City, Bangladesh: Challenges \& Opportunities
}

\author{
Md. Julhas Miah ${ }^{1}$, Md. Shahin Alam Khan ${ }^{1, *}$, Omar Faruk Misto ${ }^{1} \&$ Md.Rezaul Karim² \\ ${ }^{1}$ Shahjalal University of Science \& Technology, Sylhet, Bangladesh \\ ${ }^{2}$ Leading University, Bangladesh \\ *Correspondence: Shahjalal University of Science \& Technology, Sylhet, Bangladesh. E-mail: \\ shahinalam192@gmail.com
}

Received: June 5, 2018 Accepted: July 11, $2018 \quad$ Online Published: July 23, 2018

doi:10.5430/mos.v5n3p17 URL: https://doi.org/10.5430/mos.v5n3p17

\begin{abstract}
The main purpose of this research is to find out the challenges and opportunities that most of the women specifically those who are entrepreneurs are facing these challenges in Sylhet area, Bangladesh. This report mainly depends on some documents and some practical observations. Women Entrepreneurship is a very essential turning point for the betterment of the women. Unlike the past, women today are no longer confined in the kitchen. They have raised their voice against conservative social outlook. Now women are entering into work force which is providing them a self-identity and right to participate in family decisional affairs. In Sylhet a huge number of women are also having various types of business organizations. The women those who are entrepreneurs of Sylhet, almost 35\% are engaged in boutique businesses. There are some other businesses performed by them such as fashion house and cloth store, tailor, parlor, training center etc. Most of them have to maintain their family works despite having a business. But here they are not free from problems. The traditionalism of society, high interest rate of loan, lack of proper training facilities are the main barriers in the smoothness of business. Here every women entrepreneurs recommends that the Government should take necessary effective steps in (providing training, low rate of interest in taking loan etc.) this regard, as it is a very potential way to develop the country.
\end{abstract}

Keywords: entrepreneurship, women entrepreneurship, entrepreneurship challenges \& opportunities

\section{Introduction}

Bangladesh is a country where the resources are very limited and the population of this country is huge. In this country, the society is highly restricted as a result in this country the services and opportunities are determined by different ways like that gender, position and class. In Bangladesh the women are around half of the total labor force. That's why the ultimate development of this country largely depends on the women. In order to develop this country without the women, it is totally impossible. For the empowering of women this women entrepreneurship has a great potentialities. Women entrepreneur's class is emerging in Bangladesh because women are taking challenge of working in a competitive and sophisticated economy and business environment which is dominated largely by male. The entrepreneurship of women not only improves the living conditions and bring more respect in the society and family, but also contributes to the export growth, productivity, employment generation, business and also skills development. With the help of SMEs, Microcredit and some government initiatives women in Bangladesh are sincerely participating in many productive sectors which are necessary for the development of women's conditions.

In spite of the importance of women entrepreneurship, there are many personal, social, economic and physical confronts women are facing while they are considering to start or operating a business as an entrepreneur. Although there have been conducted many researches about the impacts of entrepreneurship which is based on mainly women on the society and economy, but it is a matter of sorrow that there are only few researches have been conducted mainly on the challenges and opportunities, where the entrepreneurships are largely based on women in Bangladesh. The main objective of this study is to find out an overview on these challenges and the way of overcoming these challenges, pointing out the opportunities, also to help the potential and present women entrepreneurs.

In Bangladesh, Sylhet is one of the largest cities. This research paper is mainly based on the data of Sylhet city, in Bangladesh. This Sylhet city has a bright prospect especially SME sector as land and labor are much cheap and 
communications with other parts of the country are well and easy. Because of the good flow of remittance the infrastructure of Sylhet is currently booming with many shopping centers, boutiques show-rooms and beauty parlous affording luxurious standards. Now Sylhet is coming out of it's conservative wrap and these potential sectors are making the women entrepreneurship highly prospective in Sylhet, Bangladesh.

\section{Research Methodology}

2.1 Sources of Data

a) Primary Data: The primary data have collected through -

- Questionnaire

- Personal interview

b) Secondary Data: The secondary data have collected from -

- Books

- Literatures

- Journals

- Newspapers

- Websites

- Article

\section{Data Analysis}

Through questionnaire the primary data were collected.18 questions were developed to know about the challenges and opportunities women are facing. While most questions were close ended, a few open-ended questions were also asked to the respondents. Demographic information were also collected. For choosing the sample, random sampling procedure was applied.

Secondary data were collected from different newspapers, internet, and articles published in journals to present some specific information about the women entrepreneurship.

In order to make the report more dependable and error free we have taken the primary data from the relevant respondents. In case of primary data we have collected the quantitative data. Besides these essential data, we also have collected the external data which is secondary data. And these data were collected from various sources such as journals, some research papers and several reports from published materials.

The structure of the data collection was fully formed. We have formed open-ended and close-ended questionnaire for respondents. All data were collected by personal interview. We have followed different statistical data and figure to find out the actual information.

\section{Sampling Method}

While collecting the data we have used the following methods:

- In Selecting Respondents: In selecting respondents, we use the convenience random sampling method, respondents who were available to cooperate with me.

- Sample Numbers: To collect data, we took 50 respondents as sample number.

\section{The Concept \& Features of Entrepreneurship}

The word "Entrepreneur" is derived from the French word "Entreprendre" that means to undertake - Singh \& Belwal.

Entrepreneur can be defined that a person who initiates and establishes some economic activities in order to earn profit by taking all the risks. The International Labor Organization(ILO) defines that an entrepreneur as a person with a set of characteristics that typically includes self confidence, result oriented, risk taking, originality and future-oriented.

Entrepreneurship is considered to be a prime mover in the development and why nations, regions and communities that actively promote entrepreneurship development, demonstrate much higher growth rates and consequently higher levels of development than nations, regions and communities whose institutions, politics and culture hinder entrepreneurship-Chouhan, Vasita \& Vyas. 
The entrepreneurial economy differs from the non-entrepreneurial economy from various aspects such as the economic structure and the economic vigorousness, the social vitality and the quality of life.

\section{The Concept of Women Entrepreneurship}

Women entrepreneurs are those who innovate imitate or adopt a business activities (Khanka-2002). For the purpose of this study the women entrepreneurs can be defined as the women running their own SMEs within the formal or informal sector.

Women Entrepreneurship is defined as the study of sources of opportunities, their identification, exploitation and consequences for the economy. Together these four components form the entrepreneurial process and provide a general model to understand how women enter into self-employment and business, how they exploit opportunities and what the consequences of women's entrepreneurship are for the economy. (Shane, 2000; Shane et al, 2000; Venkataraman,1997)

Women entrepreneurs are defined as those who use their knowledge and resources to develop or create new business opportunities, who are actively involved in managing their businesses, and own at least 50 percent of the business have been in operation for longer than a year. (Moor and Buttner,1997 in Farr-Wharton and Brunetto, 2009)

The Women entrepreneurs can be defined as that those who use their knowledge and resources to develop or create the new business opportunities whether informally in a home environment or formally via business registration, hiring office premises, etc. The women entrepreneurs who are actively involved in managing their businesses, are totally responsible for the day to day running activities of the business and have been in operation for longer than a year.

\section{The Conceptual Framework of Women Entrepreneurship}

The influences of women entrepreneurship on the social and economic arena can be depicted into a framework.

\begin{tabular}{lll|}
\multicolumn{1}{c|}{ Social Impact } \\
$\rightarrow$ Education \\
$\rightarrow$ Training \\
$\rightarrow$ Age \\
$\rightarrow$ Initial investment \\
$\rightarrow$ Duration of business \\
$\rightarrow$ Monthly returns
\end{tabular}


The women entrepreneurship's influence on the social and economic arena can be depicted a framework. Basically, Women entrepreneurship depends on some variables such as the source of capital, initial investment, education, training, age, duration of business and monthly returns. Besides the positive impacts of women entrepreneurship, it has also some negative impacts on the social status of women, women's rights, self-dependency, the eradication of gender discrimination, and self inspiration. The women entrepreneurship has a great impacts on the socio-economic sphere which helping the women to earn some extra money for the family, creating the employment opportunities for them and also for others, enjoying economic freedom, and also gearing up the process of economic development. Besides finding out the actual information about the women entrepreneurship specifically in Sylhet, this study will also try to find out the relationship between the women entrepreneurship and it's impacts on some sectors specifically on the socio-economic sphere of life. In this study the impacts of women entrepreneurship and socio economic were identified as dependent and independent variables on the basis of a casual relationship.

\section{Women Entrepreneurship in Developing Countries}

Women from low to middle income countries such as Russia, the Philippines and India were more likely to enter early entrepreneurship when compared to the higher income countries such as Belgium, Australia and Sweden a recent study have found. There are some reasons that the women from low income countries are more likely to enter early stage entrepreneurship than the women from high income countries. But all of them the significant factor is that the women from low income countries often seek an additional means of income to support themselves and also their families. Overall of all small businesses women are owned 40 to 50 percent in developing countries. Alternatively, it is not seen as beneficial to exhibit feminine traits in western business practices.

More women entrepreneurship exists in developing countries where traditionally higher birth rates prevail. The law and customs of marriage have higher rate of influence whether a women chooses to be an entrepreneur. Obstacles and problems regarding the development of entrepreneurship among women different researches have been done. The barriers of women entrepreneurship are lack of self confidence, experience, skills, modeling and knowledge as well as having different roles and responsibilities along with the existing gap between graduating and business involvement, in developing countries these are more found than the developed countries. The attitudes and employment practices in low income countries generally speaking are less likely to provide child care, health care and training opportunities to women as employees. At the same time, employers are less likely to provide a comfortable workplace and a set of adequate work practices that allow a woman to both perform satisfactorily on the job and care appropriately for her children.

As a result, women in low income countries have strong incentives to create their own work environments that are compatible with their child rearing and household responsibilities at the same time. This tendency is more strengthened in typically lower degree of involvement in child care by fathers in poorer countries. Consequently, women look for home based business opportunities preferably.

\section{Challenges Faced by Women Entrepreneurs}

There are some challenges women are facing in the entrepreneurial process of creating, nurturing, however problems faced by women in practice are of different dimensions and magnitudes, owing to social and cultural reasons.

\subsection{Sources of Capital}

The source of capital is one of the major problems for starting an enterprise which is faced by women entrepreneurs.

\subsubsection{Savings}

Women Entrepreneurs of Bangladesh face some sorts of problems to access formal and informal loans because of backward education, lack of experience, lack of knowledge, lack of access to market etc. So if they are quite sure to open a business, then they start it from their own savings.

\subsubsection{Credit}

Credit is the most valuable instrument of the development of the small and medium size women enterprise. Besides, small and medium size enterprise play crucial role in the direction of the future development. 


\subsubsection{Training}

Necessary Training is very important to start a business for an entrepreneur specifically women entrepreneur. But in Bangladesh there is no sufficient access to different trainings such as vocational and technical training. Although there is availability of training, women may be unable to access these training because the women have to be very busy for meeting the family responsibilities. Besides this, most of the trainings such as technical trainings are offered to girls at the levels of post school. So because of the backwardness of access to education and missing or not getting training opportunities, women start their businesses without adequate skills.

\subsubsection{Education}

Women have less accessibility to education than men. In order to change this less accessibility of women to education the vocation and technical trainings are very important. In fact a strong foundation of primary and secondary education can help to develop the skills of technical and vocational. In Bangladesh, the enrolment of women in education is low. Besides the dropout rates are very high and the quality of education is very poor. As most of the women are uneducated, they find it more difficult to get financing from banks.

\subsubsection{Socio-cultural Environment}

There are some characteristics that clearly distinguish the businesswomen from their male counterparts. All of them the essential characteristics are the added responsibility. Society often puts upon them in the roles as mothers and wives. It has become the common that the women's place is at home and the first priority of her is to look after the family and home constrain many married women from venturing into entrepreneurship. Marriage results in geographical displacement which is also a great constraint for the women entrepreneurship.

\section{Women Entrepreneurship in Bangladesh}

Women entrepreneurs encounter only one third of all entrepreneurs. And as half of the population in Bangladesh is women, there is an unnatural gap between the genders. There is thus potential to enhance the level of women entrepreneurs. Women entrepreneurs have a massive potential which are yet to be unleashed. Not only due to the gender gap, but also because women bring in diversity to the innovation process.

Women entrepreneurs can possibly lead to another kind of innovation. Women entrepreneurs are mainly employed in the service sector that is Tourism, ICT, Health, Social services etc. A common factor is the great potential of these sectors. Together with creative and new ways of thinking innovation, involving the consumer and the gender gap the potential women entrepreneurs are obvious.

Other Necessities of Women Entrepreneur are:

- Needed for increasing National Income of Bangladesh: They are half of our total population. Without this half of total population of nation, it is quite impossible to be developed.

- Needed for increasing Living Standards: According to Bangladesh Economy, mainly man as a key person of a family runs the family. Most of the time it is difficult to run family alone by the man's Income.

- Needed for establish themselves: According to Bangladesh culture, men dominate the women. After marriage they become victim. Most of the time men beat them and try to criticize them in various ways. If they can establish, they can reply them.

- Needed for creating Job Employment.

- Needed for proper use of the resources and take the advantage of globalization

\section{The ASIA Foundation}

The ASIA Foundation is a non government, and a non profitable organization which is professing a commitment to the development of a peaceful, prosperous and open Asia -Pacific region. This Foundation supports the Asian initiatives to improve governance, law, and civil society, women's empowerment, economic reform and development, sustainable development and the environment, and the international relation. 


\section{District Women Business Forum}

Women's economic empowerment is widely recognized as a key driver of poverty alleviation and sustainable economic growth. However, the women entrepreneurs are still hindered by discriminatory laws, policies, and cultural practices that discourage them from starting, owning, and operating successful businesses, particularly in non-traditional sectors. Women face a distinct set of challenges that impede both their entry into business as entrepreneurs, and later their ability to ensure the survival of their businesses. For example, women tend to be excluded from the ownership of assets and properties, making formal-sector financing difficult to obtain. They lack networking connections to district-level value chains and platforms for interacting with policy makers, and they are often uniformed about effective means to find the customers and suppliers, market their products, and diversify their businesses to enter profitable sectors.

Recognizing the potentialities of women entrepreneurs, and the importance of women-friendly business environments, the Asia Foundation has brought special attention to develop the women's capacity to join forces and be more proactive in pushing for reforms. This work started at the village level in 2006, and has gradually progressed to the national level and regional levels, incorporating training, policy advocacy, and networking activities. Alongside the progression from the village level upwards, the Foundation's work is empowering women. The women entrepreneurs have also expanded to include emerging sectors that have traditionally not been the domain of women. Foremost among these are the Information and Communication Technology (ICT) sector, which is rapidly expanding in Bangladesh, and which has the tremendous potentiality to create the income-earning opportunities. The ASIA Foundation is partnering with several organizations in projects that address the challenges faced by women entrepreneurs to help then diversify into new ICT-related businesses. The focus of these projects is skill development of women and the creation of linkages with between women's business and the ICT sector.

The ASIA Foundation in collaboration with Banglalink, a leading mobile telecom operator has designed a mobile-based network as a tool to increase the opportunities of women entrepreneurs to access to the information and networking. The project objective is to promote the women's entrepreneurship and ownership and management of MSMEs, particularly through the capacity building of women entrepreneur's associations using the information and communication technology (ICT). The Foundation will accomplish this objective by strengthening and expanding the women entrepreneurs access to information through the strategic use of mobile phone technology and enhancing the voice and influence of women entrepreneurs through networking opportunities and advocacy with key stakeholders.

The project titled "Connecting Women Entrepreneurs through Innovative Use of ICT" focuses on removing the barriers of women entrepreneurs, particularly in the realms of business entry and access to finance and markets. The Foundation will build on the success of it's established programs that have improved the business environment for MSMEs in Bangladesh by working closely with the existing DWBF's to create the mobile -based network. The project will initially be implemented in four districts: Barisal, Rajshahi, Rangpur, and Sylhet, with the prospect of later expansion to more districts.

\section{Sylhet Women Business Forum}

The Sylhet Women Business Forum (SWBF) was established in July, 2009. The founding president Mrs. Shornolata Roy has boosted up this platform for the women entrepreneurs of Sylhet city. This forum is more active than the four others. Among 200 members of the forum of 50 members are very active. It is run by an executive committee which is consisting of 15 members. They call for a meeting every month and discuss their initiatives. Members file up different problems regarding their business and the committee brings up a possible solution by discussing with others. It is like a family to the women entrepreneurs. The office of SWBF is located at Jamtola, Sylhet. The SWBF works with the women entrepreneurs for the betterment of their business. The purposes of the Forum are:

- Arrange training to bringing up new entrepreneurs.

- Help entrepreneurs to get loan on less condition.

- Help women entrepreneurs to sell their products by arranging fair.

- Help new entrepreneurs to get Trade License.

- Help them to get VAT and TIN License.

- Help women entrepreneurs through different Government or Private Organizations. 
During this short time of establishment SWBF has gained remarkable achievement. It has showed the women entrepreneurs the courage to dream in a conservative area like Sylhet.

$\checkmark$ SWBF has managed to pass loan for 100 women entrepreneurs.

$\checkmark$ Getting Trade license is much easier now.

$\checkmark$ SWBF has distributed TIN License among 200 entrepreneurs

$\checkmark$ Through SWBF women entrepreneurs has participated in different national \& international fair.

$\checkmark \quad$ SWBF has been rewarded nationally

So, as per my observation, the Sylhet Women Business Forum is a great platform for the women entrepreneurs to enlarge their business and thus make a contribution to the family as well as the nation.

\section{Data Analysis \& Findings}

Data Analysis

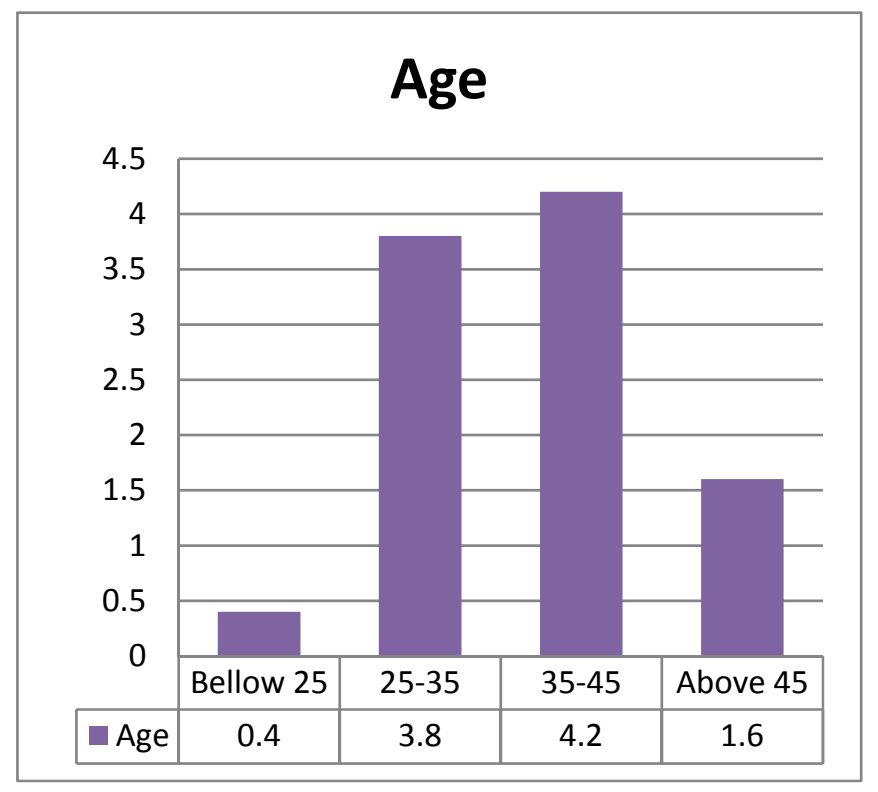

Figure 1. Percentage Distribution of Women Entrepreneurs by Their Age 


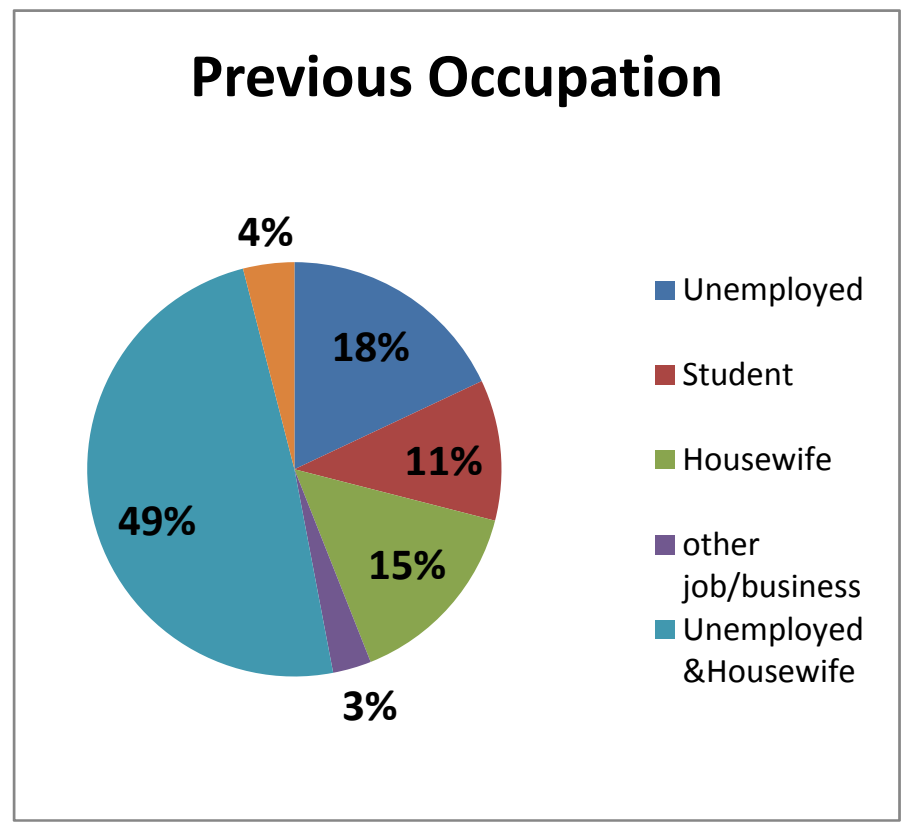

Figure 2. Percentage Distribution of Women Entrepreneurs by Their Previous Occupation

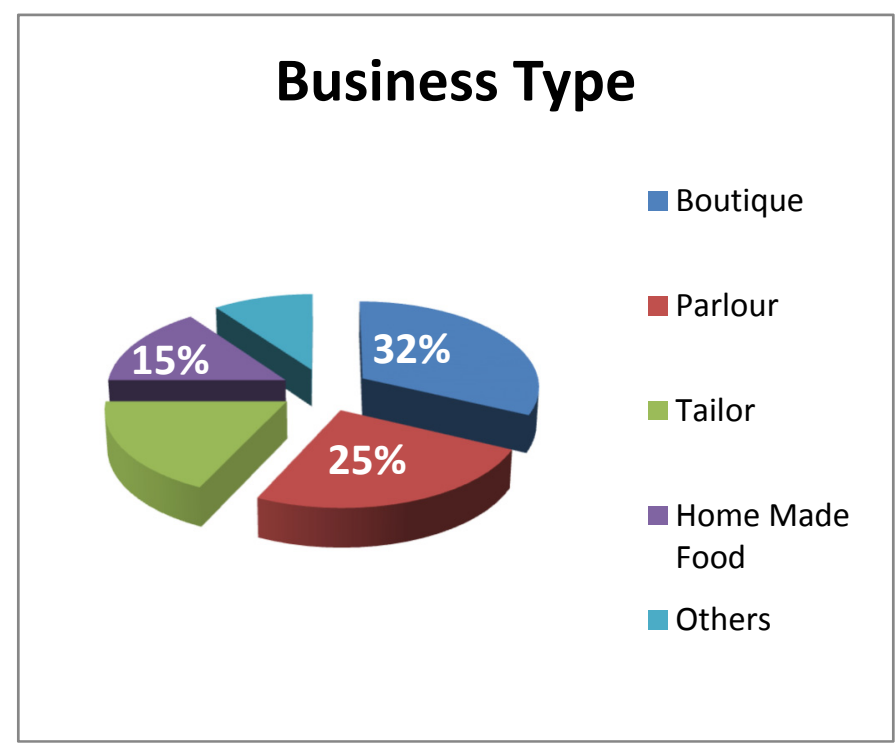

Figure 3. Percentage Distribution of Women Entrepreneurs by Business Type 


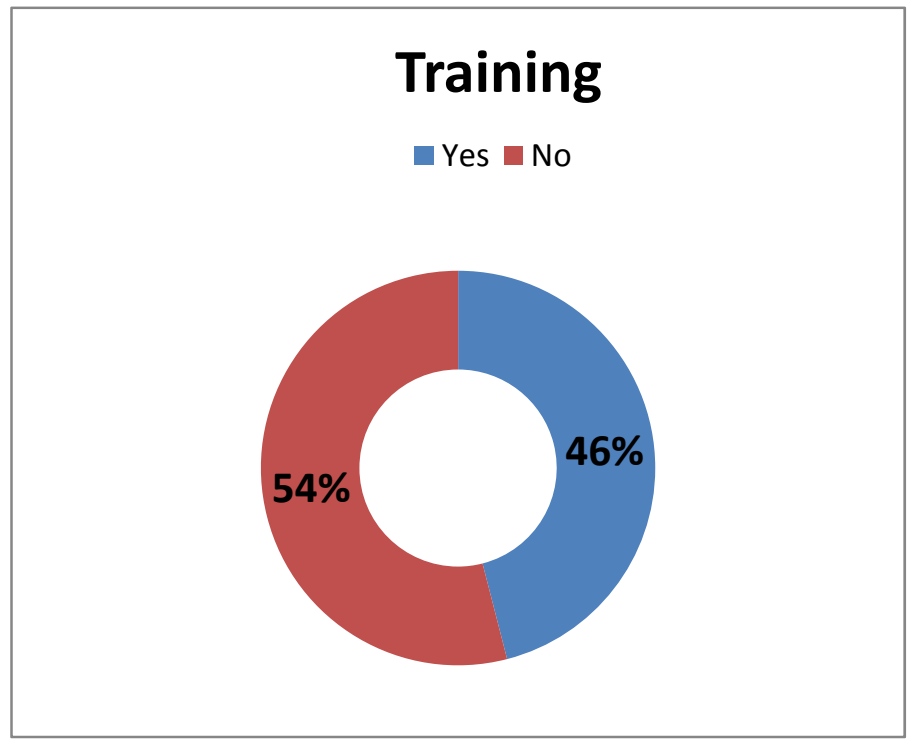

Figure 4. Percentage Distribution of Women Entrepreneurs about Training

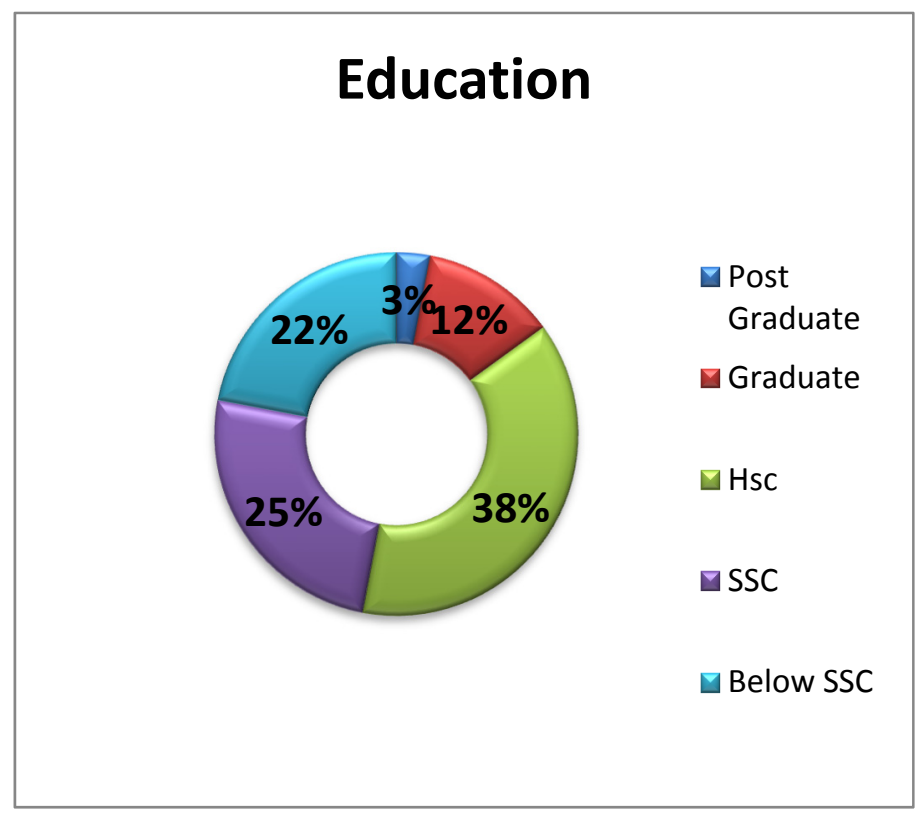

Figure 5. Percentage Distribution of Women Entrepreneurs by Their Educational Qualification 


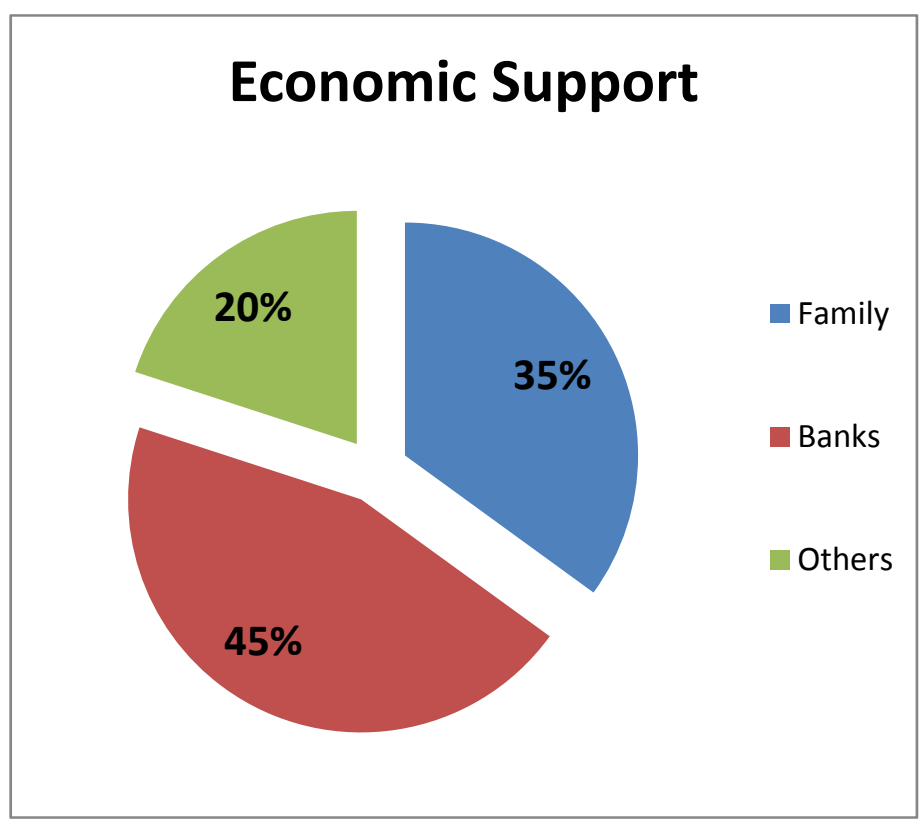

Figure 6. Percentage Distribution of Women Entrepreneurs by Their Economic Support

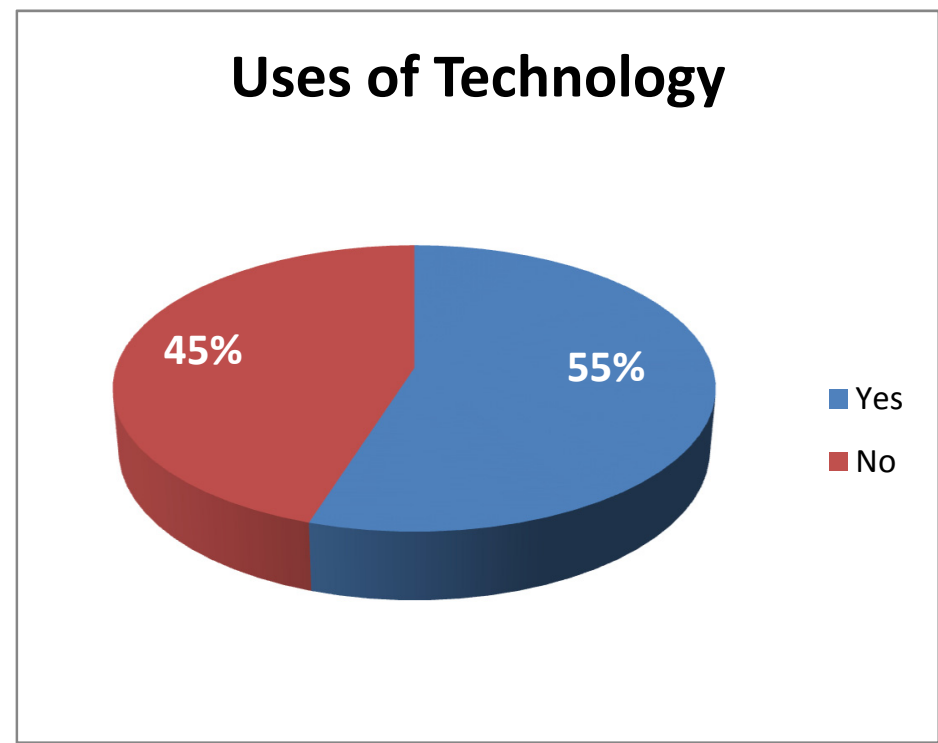

Figure 7. Percentage Distribution of Women Entrepreneurs by the Use of Technology 


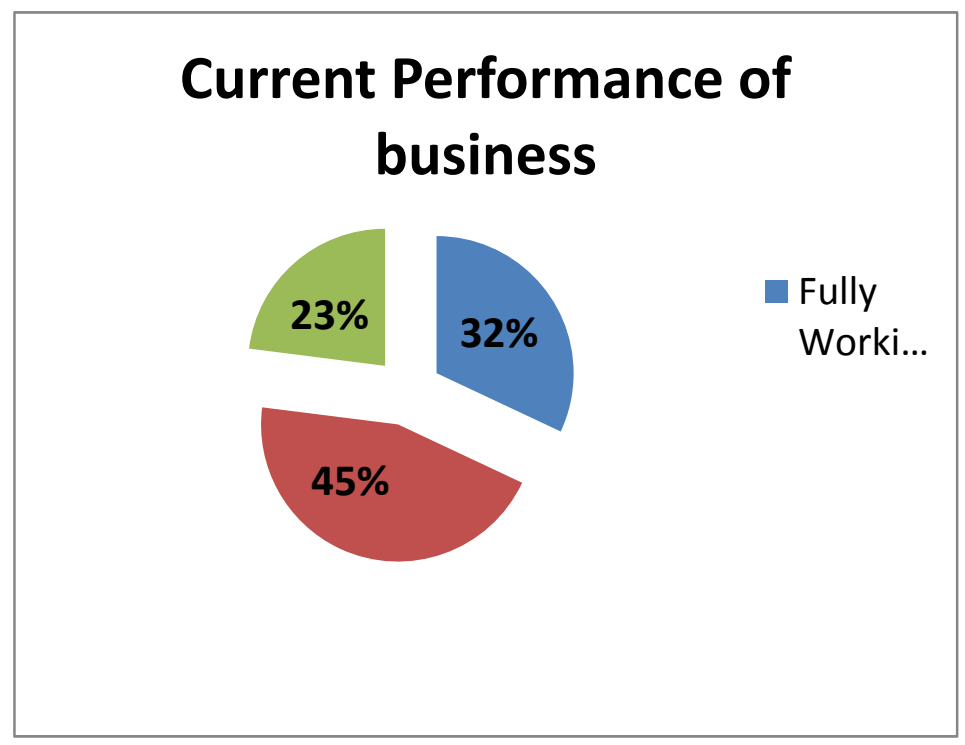

Figure 8. Percentage Distribution of Women Entrepreneurs by the Current Performance of Business

If it necessary for any research works to show it's various findings in a nutshell. Summary of findings helps reader to realize the most outstanding achievement from the study and the actual scenario of the study area.

By analyzing the primary data we can find out the challenges and opportunities faced by the women entrepreneurs of Sylhet city. Here the women are becoming entrepreneurs for the empowerment and freedom, to give their child a better future, to contribute to the family, to gain a social status and to pass the leisure time moreover for their own identity. In a society like ours women entrepreneurs have to face many hurdles and they doing it bravely. That is the key success of women entrepreneurs of Sylhet.

Most of the women entrepreneurs run boutique shop, whether from the house or shop. It is the booming business for the women in Sylhet. In second position, we can find parlors. It is tough business to do in a conservative area like Sylhet. But many women have taken the risk and they are succeeding.

* Among 50 respondents we have found that $4 \%$ respondents are below 25 years old. $38 \%$ respondents are 25 to 35 years old and maximum participants are above 35 years old.

* By searching business type we have found that $32 \%$ respondents are involved in boutique business, $25 \%$ are engaged in parlor business and rest of all are doing various types of business like tailoring, homemade food.

* $54 \%$ entrepreneurs are trained according to their business but $46 \%$ of them are not. It is very alarming. All the women should be well trained to cut a good figure in the business arena.

* By searching the source of capital of the business of the respondents we have found that $45 \%$ get capital as loan from the bank, $35 \%$ get invested by the family and $20 \%$ collect capital from other sources.

* We have found $38 \%$ respondents involved in business who have passed their HSC level, $25 \%$ are SSC passed and 22\% haven't completed their SSC level.

* $45 \%$ respondents are running their business smoothly but $23 \%$ of the respondents are still struggling.

In this report we can also find that the women entrepreneurs face restriction from the family and society. It is a big hurdle in their way to success but they are managing this problem very bravely. Now a day the amount of restriction is decreasing. It is a very positive thing for the new women entrepreneurs.

Though in past economic instability was the only reason for women for becoming entrepreneurs but now the scenario has changed. Women are becoming entrepreneurs for their own personal identification, to pass their leisure time, in a desire to do something for other women, to contribute to the community. Women are doing their business doing all the household works having their family beside them. Security problem is a great issue in a society like ours.

Women are not secured in our society. The working women face a lot of hazards. If there was a healthy environment for the women, then they could do much more for the community by their works. Women also face various problems 
to rent a shop. They have to experience bad comments from the shop owner sometimes. Sometimes they can not manage a shop to rent only because of being a woman. Many of the shop owners think a woman can not manage to pay the rent from their businesses. Bureaucratic problem is a common one. But women face this problem often.

In this report we can see that, through women entrepreneurs doing a great job in Sylhet but they are not ready to run business outside the city. If they can get help from the Government in a form of resource and guide, then they can run their businesses even outside the country.

\section{Conclusion}

Bangladesh is a developing country, where the women constitute nearly $50 \%$ of the total population. There was a time when women were treated as only the house servant who used to depend on men for their survival. But today things have been changing, now our women are coming out of their traditional four walls. They are entering into economic affairs largely. They are doing several types of business activities to support themselves and family. In Sylhet, the women are not remained lagged behind. They are engaging themselves in various business sectors. But, it is true that here the required facilities are not being provided by the authorities. If our Government comes forward to let these women cope with the changing universe, the more and more women will be independent by their entrepreneurships.

\section{References}

Begum, R. (1993). Entrepreneurship in Small-scale Industry: A Case Study of Engineering Units. Dhaka University Journal of Business Studies, 14, 159-162.

Chouhan, V., Vasita, M. L., \& Vyas, D. M. (2012). Entrepreneurship Challenges and Opportunities: Indian Scenario.

Islam, Saiful Md., \& Md. Aktaruzzaman. (2001). The Problems of Rural Women Entrepreneurs in Bangladesh: A Case Study of Jhenaidah District. Islamic University Studies (Part-C), 4(1), 19.

Khanka, S. S. (2002). Entrepreneurial Development. New Delhi, India: S. Chand Group.

Shane, S., \& Venkataraman, S. (2000). The promise of entrepreneurship as a field of research. Academy of Management Review, 25(1), 217-266. https://doi.org/10.5465/amr.2000.2791611

Singh, G., \& Belwal, R. (2008). Entrepreneurship and SMEs in Ethiopia: Evaluating the Role, Prospects and Problems faced by Women in this Emergent Sector. Gender in Management: An International Journal, 23(2), 120-136. https://doi.org/10.1108/17542410810858321 